ESJ Humanities

\title{
Democratic Governance and Social Service Delivery in Africa: the case of Taraba State, Nigeria
}

\author{
Jonah I. Onuoha \\ Rimamchaten A. Lawi \\ Paul A. Onuh \\ Ifeanyi J. Onuoha \\ Department of Political Science, University of Nigeria, Nsukka
}

Doi:10.19044/esj.2021.v17n28p35

Submitted: 14 December 2020

Accepted: 14 June 2021

Published: 31 August 2021
Copyright 2021 Author(s)

Under Creative Commons BY-NC-ND

4.0 OPEN ACCESS

Cite As:

Onuoha J. I., Lawi R. A., Onuh P.A. \& Onuoha I. J. (2021). Democratic Governance and Social Service Delivery in Africa: the case of Taraba State, Nigeria. European Scientific Journal, ESJ, 17 (28), 35. https://doi.org/10.19044/esj.2021.v17n28p35

\section{Abstract}

Postcolonial leadership is implicated in the distorted development and crisis of governance in Nigeria. The political leadership emerged from authoritarian traditions of the colonial state and pursued self-interests against collective societal interests; the mode of the emergence of the leaders as well as the context in which they operate usually impact on the nature and trend of social welfare provisioning. Relying on data from secondary sources, this study examined the impact of democratic governance on social service delivery with Taraba State and education as a case study. The data analysis was based on qualitative descriptive analysis. We found that the education sector under the two administrations between 1999 and 2014, was not prioritized in budgetary allocation, in contravention of UNESCO recommendation that $26 \%$ of the budget be dedicated to education. The study recommends, among others, that the government must show commitment to education as a matter of deliberate policy to allocate the required minimum percentage pecked by UNESCO to enhance educational development in Taraba state.

Keywords: Democracy, Governance, Social welfare, Social service delivery, UNESCO 


\section{Introduction}

Nigeria returned to democratic governance in 1999 after several decades of military rule. Since then there has been a growing thirst and demands on the political system to transform the country to improve the living standard of the people. Within the context of democratic governance, the growing demands generate a quest for open political space that allows for a proper articulation of social needs and problems to guide policy formulation in Nigeria, per the Bentham tradition that government at all levels exist for the greatest happiness of the greatest number of persons in a polity.

The provision of social welfare requires an equitably regulated socioeconomic context in which social services, social securities and opportunities are within the reach of the teeming population without discrimination. Globally, democratic governance has been credited with improvements in social welfare services that guarantee a gradual but steady improvement in the living conditions of the people. Democratic governance, therefore, presents a range of processes that brings about the implementation of regulations, human rights, laws and policies that ensures justice, welfare and environmental protection. It is about how society organizes itself to ensure equality of opportunity and equity in terms of social and economic justice for all citizens. This view is predicated on the fact that democratic governance is a social contract framed around the primacy of the people in the decisions and actions of government (Almond et al, 2007).

The quality of democratic governance in contemporary times is not only determined or measured by the institutions, structures and the processes that lead to its existence, but also by the social services the government provide to the people. Social services are mainly welfare programmes that have a direct and indirect positive impact on the quality of life of the people (Umar \& Tafida, 2015). The performance of democratic governance at the national level in terms of social service delivery should also be reflected at the subnational level. Social service delivery at the subnational level in Nigeria is rhetoric as in most circumstances the impacts are not felt by the people. While Nigeria is regarded as one of the developing countries, in terms of the provisions of requirements necessary for improved living conditions across the country, Taraba State as a component state in Nigeria is considered an underdeveloped state in Nigeria.

Nigeria's experiment with democratic government since 1999 has not yielded the desired results due to extreme level of corruption, crude politics, civilian authoritarianism, selfishness and greed of the political leadership (Varshney, 2010). The deteriorating standard of living of the majority of citizens in rural and urban areas is due to the absence of good governance. The much-needed development in terms of social provisioning has continued to elude the people in Taraba State as many of the people are living below the 
poverty line. This is despite the huge federal allocations and revenue sources available to the Taraba State Government. In Nigeria, the politics of democratic governance as relates to social service delivery reveals that the country is rated far below expectation in terms of human development. In many states across Nigeria, many people are living without access to safe sources of water, even in urban areas. Ensuring adequate sanitation has become problematic as refuse dumps litter major streets, healthcare facilities are not adequately provided for, and people still die of preventable diseases (Onwe and Chibuzor, 2015).

In Nigeria, although the demands of social service delivery are myriad and high among various sectors of the country, the education sector is considered to be more critical as a driving force for other sectors. Education, whether formal or informal, has the capacity of inculcating lifelong learning and knowledge that will spur the development of ingenuity and progress to the individual, community, and society at large. The education sector has suffered neglect from various levels of governance in Nigeria. The government's insensitiveness to the education sector in the country can be seen in the budgetary allocations the sector has received over the years. The global benchmark presented by the United Nations Educational, Scientific and Cultural Organization (UNESCO) for the education sector is 26 per cent of the national budget of the country (Aniekwu \& Ozochi, 2010). However, the Nigerian education sector has seen far less. This study examined the nexus between democratic governance and social service delivery in Taraba State with a focus on the education sector, between the period of 1999 and 2014.

\section{Conceptual Clarifications}

Democracy

The discourse surrounding democracy cannot be overemphasized. The concept is myriad, ambiguous, reflecting on different aspects and phases of development. The conceptions of democracy mean different things to different people, because it depends on the specificity of its adoption and applicability within a given context of definition and operationalization. However, what is universal to all perspectives on democracy is the concept of "the people" (Held, 1996; Almond et al, 2007). Johari (1989) conceptualized democracy as a form of state, and it prevails where people are powerful or the sovereign authority is vested on the people. For Birch (1995), democracy implies a degree of social equality and not necessarily a form of government. In this context, the whole of democracy is the people or it is all about the people. There is a primacy to the people, as they participate in governance directly as in the case of Athens or indirectly through their representatives. 


\section{Democratic Governance}

There seems to be a strong nexus between democracy and governance. Democratic governance is a system that upholds the ideals of having institutions function according to democratic processes and norms, both internally and in their interaction with other institutions (OSCE, 2017). Democratic governance is factored from the action-ability of the political institutions in a democratic system to perform certain responsibilities and to be accountable at all times, which can manifest through policy decisions and actions as well as laws carried out by the institutions, which include principally the legislature, judiciary and executive branch, and other political parties, private sector and a variety of civil society (Dahl, 1989; Held, 1996). For Fritz \& Menocal (2007), the operation of democratic governance must be situated within the rules that regulate the public realm, the processes and institutions where the state, as well as economic and societal actors (both national and international), interact to make decisions because of the effects of their activities on the people.

From the foregoing, it is deductible that democratic governance involves transparency, accountability, low levels of corruption and a decentralized decision-making structure and programmes which have been a critical contributor to one's country development (David, 2010). In this sense, democratic governance brings to the fore the question of how a society organizes itself to ensure equality (of opportunity) and equity (social and economic justice) for all citizens.

The emphasis on democratic governance from the above context goes beyond the procedural processes of democracy and the establishment of democratic institutions, to the promotion of the sustainability of democracy through an enduring capacity for the separation of powers and independence of the branches of government, the exercise of power under the rule of law, the respect for human rights and fundamental freedom; and, the transparency and accountability of responsible civil service, functioning at both the national and local levels (Ozor, 2009; Igbuzor, 2010; Momoh, 2010).

\section{Social Service}

Social service constitutes a set of programmes that are developed to achieve certain goals within a given social system or political community called the state. Social service generates from deliberate social policies of the government directed at the making of positive changes not only in the structure and institutions of the state but to also improve the quality of life of the people in the state (Olewe, 1995; Ujo, 2007). Social service, therefore, cannot be complete without the making of decisions and actions, which manifest in terms of programmes carried out by the government and its agencies that are directly related to the provisions of welfare services to people and the community. 
Some of the social programmes include child protection, free education, healthcare services, and housing. These programmes enable the people to attain the level of self-actualization and also help prevent the spontaneous reactions against the state for being non-responsive and accountable to the people as a matter of democratic regime (Ayo, 1988). The central focus of the provision of social service is about empowering people and alleviating them from poverty (Olewe \& Anga, 1994).

\section{Social Service Delivery}

The concept of social service delivery is also one of the major issues that have attracted a lot of debates and concerns among policy scholars, policymakers and publicists. Social service delivery, sometimes referred to as "dividends of democracy", is at the heart of democracy. Often, the perspective associated with democratic governance has been associated with the fact that the government emerged from a free, fair and credible electoral process (Diamond et al, 1989; Held, 1996; Ake, 1996). On the contrary, an election is just the starting point of a democratic government. Democratic governance goes beyond the guarantee of human rights, which are demonstrated through the exercises of freedom of association, speech, and so on, as well as responsiveness and accountability. Social service delivery has become a yardstick for measuring democratic accountability and responsiveness. These include social services (primary education and basic health services), infrastructure (water, sanitation, roads and bridges) (Kayode et al, 2013).

\section{Theoretical Framework}

This study is anchored on the neo-Marxist theory of the postcolonial state. The postcolonial state theory was developed by Hamza Alavi in 1972 to study the political character of the states in postcolonial societies, particularly Pakistan and Bangladesh. The postcolonial state theory is adopted because of its capacity for examining and explaining the manifest character of the social structures in Nigeria's postcolonial state. Alavi (1972), while reacting to the Western or liberal perspective of the state, questioned the basic tenets of the classical theory of the state in the context of postcolonial societies, taking into consideration the concept and purpose the state is meant to serve. The state is viewed from the standpoint of being a product of contradictions and irreconcilable class relations (Lenin, 1976). According to Ifesinachi and Anichie (2014), class relations are power relations, which manifest in a character, described by Lenin (1976:9), as where “...group of people differ from each other by the place they occupy in a historically determined system of social relation of production." 
Ibeanu (1998) argued that the foothold of colonialism sustained in the postcolonial state was such that anti-colonial struggles in Africa altered little or nothing at all in the arbitrariness of the predecessor of the postcolonial state. In the postcolonial state of Nigeria, the change was only in the personnel of the colonial state, the structures remained unchanged. The prevalence of this character in postcolonial states in Africa, particularly in Nigeria can be attributed to some factors, which included the inheritance of an overdeveloped state with weak economic base and lacking in the capacity to respond to the needs of the "subordinate indigenous social classes" (Alavi, 1972; Saul, 1974:5), which supposedly should be in the form of the provisions of social services. Because of the overdeveloped and weak economic system, there is no economically dominant class in the social formation of relations, the interest of the comprador class conflicts because the postcolonial state represents itself as a means of acquiring political and economic power. Those who control the state use its machinery to further their economic interest since it is a major means of production.

The relevance of the theory in the context of Nigeria stems from that fact that it does not only reveal the dependency of social consciousness and the entire social structure, but also the totality of social relationships, structures and institutions by examining the existing productive forces of society and reluctant productive relations and the ideological superstructure built upon them (Ray, 1999). The question that comes to mind is, has the government in postcolonial Nigeria state lived up to the expectation of the people, which are the provision of education, water supply, electricity, and road construction, among others dubbed as social services? Without sounding too categorical, it does seem that the government has not. Not many of the public officials render accounts of their stewardship sincerely and genuinely. Ganchok (2006:2) must have had this in mind when he asserted that:

Our nine years of democratic experience can be likened to still born-child. We voted for our own people to represent and protect our interests, but we were paid back with poverty, hunger and ill-health. Our democratic years were a complete waste. Administration was left in the hands of juveniles who mortgaged our future and that of our grandchildren to bank loans and overdrafts.

In Nigeria, due to the erosion of sovereignty almost all social services are sought for privately. As observed by Obianyo (2009:86) and cited in Ekpe (2011:185): 
Individuals organize to repair roads leading to their residence, security is privately organized in what is popularly known as vigilante groups, private electric generating sets have replaced electric supply by the state, water comes from commercial boreholes and plastic containers. Workers in government today save their pension while in service - in fact private hospitals proliferate the cities as the state-owned ones deteriorate and become house of deaths due to lack of basic facilities and drugs.

The situation cited above is far more entrenched in the educational system in Nigeria. There is a wider gap that is being created and entrenched by the dominant class by ensuring that public schools, which are supposed to be the responsibility of the government to sustain, are poorly managed. Several public schools at both primary and secondary levels are in dilapidated conditions following the government lukewarm attitude towards the sector (Akpeji, 2015). For instance, in the Taraba primary education system, the signs of deterioration can be seen in every aspect. These include the poor state of physical facilities (building and furniture for teachers and pupils) and health-related facilities. The provision of instructional materials is not adequate, and there are unqualified teachers in the teaching service in primary schools (Yusif, 2008).

Twenty-four years after the state was carved out of the defunct Gongola state; several public schools are still operating from their temporary sites. Even those that manage to relocate to their permanent sites, still lack basic school structures to support effective learning for both students and teachers. Maintenance work and renovation has not been carried out on the physical structures of most of the public secondary schools in the state in the last two decades (Oruonye 2014).

\section{Democratic Governance and Social Service Delivery in Nigeria}

Nigeria's democratic governance has been epileptic since independence in 1960. The Civil war (1966-1970) and military interventions and staying in power for over three decades undermined the practice of democracy. Since 1999, Nigeria has been governed by successions of democratically elected leadership. However, the practice of democracy in Nigeria is not without its challenges emerging from its dysfunctionality, causing disenchantment among its population. Part of the central purpose of social service delivery is poverty reduction. Several elements are intricately 
linked to poverty reduction, which include among others the provisions of facilities that can enable poverty reduction. These are enhancing the availability and affordability of education, health and empowering women through entrepreneurial and employment creation opportunities (Hernandez, 2006). According to Hoogwout (2010), improving social service delivery to individual citizens raises trust in the government.

With the return to democratic governance in 1999, the people have not been in the driving seat of development and beneficiaries of the dividends of democracy as expected. The provision of social services in Nigeria is governed by certain pricing policy of public utility services such as the roads, sewage and education, etc. the major question then is who benefits from the goods and services provided by the public sector enterprises? According to Lysias \& Fidelis (2014) democracy in Nigeria neglects the welfare of citizens. Nothing else best explains this situation than the issue of governance. Essentially, politicians have conducted themselves in manners that are devoid of accountability, transparency and responsiveness. The absence of welfare, for which politicians have at best become rhetorical about, is a deficit in Nigeria's democracy (Lysias \& Fidelis, 2014: 528).

The challenges associated with social service delivery in Nigeria are prevalent in health services. Majority of Nigerians are poor and find it difficult accessing health services across the country. For such people to access health services, they have to rely on extended families. Studies show that health facilities are limited and where they are available, the required service providers are hardly found to render health services. In a study conducted in Rivers state, Akujuru (2015) revealed that drugs and other facilities are undersupplied and these centres are lacking in qualified personnel. Patients pay user fees and purchase medication which sometimes they cannot afford because the drugs are expensive. This result increases infant mortality, thus 94 of every 1000 births die and the life expectancy for Nigerians is only fortyeight (48) years. Malaria and other curable diseases remain the major cause of death. Other preventable ills that government has been unable to halt include measles, whooping cough, polio, Cerebrospinal meningitis, gastroenteritis diarrhoea, tuberculosis, bronchitis and sexually transmitted infections with Acquired Immune-Deficiency Syndrome (AIDS) becoming more prevalent.

This situation is more evident in most parts of Northern Nigeria, where government both at the state and local government level demonstrate a high level of irresponsibility and lack of accountability. UNICEF report (2014) shows that preventable or treatable infectious diseases such as malaria, pneumonia, diarrhoea, measles and HIV/AIDS account for more than 70 per cent of the estimated one million under-five deaths in Nigeria. 
In a related development, Oruonye (2014) posited that funding of the educational system in Nigeria has been identified as one of the most pervasive and the greatest challenge to quality education and training of all categories of professionals in the country. Experts agree that the most serious problem facing the Nigerian educational system is the manner, in which the sector is funded, organized, planned and administered (Aniekwu and Ozochi, 2010 in Oruonye, 2014: 501). Other factors for poor education in Nigeria include monetary cost, insufficient interest, distance of schools, and general poor quality of schools. Central to these challenges is the failure on the part of the government to take education seriously in Nigeria.

The United Nation's Education and Scientific Committee (UNESCO) recommended standard budgetary allocation to the education of $26 \%$ of the state budget to engender proper development in that sector and in appreciation of the key role of that sector in economic development. For the past 20 years, no government in Nigeria has been able to meet this minimum standard and indeed, since 1999 and the advent of democratic rule in Nigeria, the budgetary allocation to education has not risen beyond 10\% (Aniekwu, and Ozochi, 2010 cited in Oruonye, 2014). In his finding, Amoo (1982) in Oruonye, (2014), observes that poor staffing has been a recurring feature in the country's educational system. The educational system in the state has been plagued by far too many work stoppages by teachers asking for improved conditions of service.

\section{Continuities, Challenges and Changes in Education Sector in Taraba State, 1999-2014}

Education among other sectors is seen as the bedrock of human capital development. Education in Nigeria, especially at the state level, is in daring need of a revolution. In Taraba State, the case of the education sector cannot be entirely separated from the national reflections. Taraba State has received a huge budgetary allocation from the federal government within the period under consideration as shown in table 1. 
Table 1: Federal Account Allocation Committee (FAAC) to Taraba State, 1999-2014

\begin{tabular}{|l|l|}
\hline 1999 & $\mathrm{~N} 3,075,221,560.44$ \\
\hline 2000 & $\mathrm{~N} 6,775,026,901.61$ \\
\hline 2001 & $\mathrm{~N} 10,324,601,812.10$ \\
\hline 2002 & $\mathrm{~N} 11,055,815,228.50$ \\
\hline 2003 & $\mathrm{~N} 13,301,256,134.26$ \\
\hline 2004 & $\mathrm{~N} 17,209,156,234.36$ \\
\hline 2006 & $\mathrm{~N} 20,983,409,561.09$ \\
\hline 2007 & $\mathrm{~N} 21,961,332,092.22$ \\
\hline 2008 & $\mathrm{~N} 26,177,099,838.81$ \\
\hline 2009 & $\mathrm{~N} 33,417,662,819.63$ \\
\hline 2010 & $\mathrm{~N} 39,248,805,395.30$ \\
\hline 2011 & $\mathrm{~N} 49,970,411,863.15$ \\
\hline 2012 & $\mathrm{~N} 43,201,504,591.00$ \\
\hline 2013 & $\mathrm{~N} 51,169,504,257.24$ \\
\hline 2014 & $\mathrm{~N} 54,376,659,914.26$ \\
\hline Grand Total & $\mathrm{N} 58,009.604,097.86$ \\
\hline & $\mathbf{N 4 6 0 2 5 7 0 7 2 3 6 1}$ \\
\hline
\end{tabular}

Source: Taraba State Planning Commission

The allocations seen in table 1 were made for the state to deliver on individuals' campaign promises and provide social services as the basics of the supply-side of democracy. FAAC allocations are spent on recurrent items and capital projects. With regards to the education sector in Taraba state, which is an aspect of social welfare, and important to human capital development, it has not attracted much government attention. In table 2 the budgetary allocation to the education sector between 1999 and 2014, indicates that the percentage of the total budget is inconsistent. It shows that the education expenditure was not considered as policy priority in the overall budgeting, or else they would have maintained an increasing proportion of the yearly budget of the state/nation (Lawanson 2009 cited in Owolabi and Okwu, 2010). 
Table 2: Taraba State Budgetary allocation to the Education Sector, 1999-2014

\begin{tabular}{|l|l|l|l|l|}
\hline S/No & Year & Total Budget & $\begin{array}{l}\text { Education } \\
\text { Allocation }\end{array}$ & $\begin{array}{l}\text { Percentage of } \\
\text { Total Budget }\end{array}$ \\
\hline 1 & 1999 & $3,075,221,560$ & N/A & N/A \\
\hline 2 & 2000 & $6,775,026,901$ & N/A & N/A \\
\hline 3 & 2001 & $10,324,601,812$ & N/A & N/A \\
\hline 5 & 2002 & $11,915,838,955$ & $579,639,910$ & 4.7 \\
\hline 6 & 2003 & $12,256,075,530$ & $768,000,000$ & 6.3 \\
\hline 7 & 2004 & $17,209,156,234$ & N/A & N/A \\
\hline 8 & 2005 & $20,983,409,561$ & N/A & N/A \\
\hline 9 & 2006 & $24,231,108,748$ & $2,131,940,285$ & 8.8 \\
\hline 10 & 2007 & $31,934,660,280$ & $2,332,768,000$ & 7.3 \\
\hline 11 & 2008 & $37,560,261,475$ & $4,230,000,000$ & 11.3 \\
\hline 12 & 2009 & $31,330,808,656$ & $5,000,000,000$ & 15.9 \\
\hline 13 & 2010 & $64,144,351,808$ & $6,797,864,854$ & 10.6 \\
\hline 14 & 2011 & $43,670,650,932$ & $5,482,891,265$ & 12.6 \\
\hline 15 & 2012 & $73,852,442,531$ & $4,725,760,882$ & 6.4 \\
\hline & $2013 / 2014$ & $73,415,972,736$ & $4,900,000,000$ & 6.7 \\
\hline
\end{tabular}

Source: Taraba State Ministry of Finance, Jalingo. N/A = Not Available

Table 2 shows that though the state has received increasing budgetary allocation from the federal government over the years, the education sector continued to receive less. The increase in the education budgetary allocation only saw an increase in the year 2008 reaching its peak in 2009 and fluctuated in 2010 and then rose in 2012. It nosedived in subsequent years. UNESCO recommended 26 per cent of the total budgetary allocation to the education sector. Evidently, from the pattern of budgetary allocation in Taraba state within the study period, the UNESCO expectations have not been attained.

In Taraba State, the population of school-age has been increasing at a geometrical rate but the establishment, constructions and rehabilitation of schools at all levels has been at the arithmetical rate since the state was created. In Table 3 it is noticeable that even though it may appear that the state through its deliberate policy framework has deployed interest and commitment toward salvaging the illiteracy rate in Taraba state as one of the less educated states in Nigeria, it also shows that with sixteen local government areas, only 1265 schools were established or constructed between 1999 and 2014. On the average, each local government was to get only 79 schools, which is not enough to cater for the education needs of the people in the State (Taraba State Annual Census, 2014/2015 Report). 
Table 3: Schools established in Taraba State from 1999 to 2014

\begin{tabular}{|l|l|l|l|l|l|l|l|l|l|l|l|l|l|l|l|l|}
\hline $\begin{array}{l}\text { Year of } \\
\text { establishment }\end{array}$ & 1999 & 2000 & 2001 & 2002 & 2003 & 2004 & 2005 & 2006 & 2007 & 2008 & 2009 & 2010 & 2011 & 2012 & 2013 & 2014 \\
\hline $\begin{array}{l}\text { No. of Schs. } \\
\text { Established } \\
(1999-2014)\end{array}$ & 100 & 180 & 89 & 50 & 67 & 63 & 55 & 66 & 160 & 68 & 69 & 105 & 51 & 45 & 54 & 43 \\
\hline
\end{tabular}

Source: Taraba State Annual Census, 2014/2015 Report.

From the foregoing, it is evident that the period which there was a serious commitment by the government to establish and or construct more schools was between 1999 and 2000 where 100 and 180 schools were established across the state respectively. This period was under the leadership of Governor Jolly Nyame. Another period when government established schools were in 2007 and 2010 where 160 and 105 schools were established respectively. This period was under the Governor Danbaba Danfulani administration. It is imperative to state that both administrations did not perform remarkably in improving the education sector in terms of establishing schools as a marked feature of social service delivery.

Again, it is also important to demonstrate that the establishment of schools in the sixteen local government areas in Taraba state was not evenly distributed between 1999 and 2014. This is shown in figure 1. Sarduana, Karim-Lamido, Takum and Wukari Local Government Areas respectively had a higher number of established schools. The least advantaged were Jalingo, Donga and Gashaka Local Government Areas respectively. As the uneven nature of the distribution of schools in the state, so was also the distribution of schools across the local government areas. Some of the schools were established based on some primordial considerations or interests such as ethnicity, religion or political affiliations. 
Figure 1: Number of Primary Schools by LGA, 1999-2014



Source: Taraba State Annual Census 2014/2015 Report.

However, the majority of these schools exist only on paper documents. Most of the schools were created by the heads of primary and post-primary education boards with names of ghost-workers, who are paid but the salaries are siphoned. This situation has had a serious impact on the development of education in Taraba state.

The recruitment of staff in schools in any state like Taraba state is of paramount concern. This is because it is a known fact that the State is an educationally less privilege state. In any state, primary education is seen as being fundamental to a child's development and future attainment in life (Obiweluozor, 2015; Federal Republic of Nigeria, 2012). Primary education is the foundation of formal education. It is an essential component in the echelon of the educational system of every nation (Asodike and Ikpitibo, 2014).

To qualify for other levels of education, one must first pass through primary schools, as such, it is an institution upon which all other levels of education and educational achievements are built. It prepares the mind and trains the child for higher and tougher academic pursuits. It provides young learners with the fundamentals of reading, writing, skill acquisition, information and attitudes necessary for proper adjustment into the society (Adesina, 2011; Jaiyeoba, 2007). This is because primary education, according to the National Policy on Education (NPE, 2004), is likened to the key which opens to success or failure of the whole educational system (Quadri, 2001). As important as the primary and pre-primary education to the development of a child, also other levels of education, such as secondary and 
tertiary schools are important and require serious attention and commitment from the government as a matter of social service provision to the people.

Fundamentally, recruitment is an act of attracting people with the right qualifications to apply for a job and if an individual is found suitable for a particular job is employed (Jokthan, 2013). In Taraba state recruitment of primary schools teachers hardly takes place, rather those in control of the primary education board from time to time fill in their candidates to those schools needing workforce. These individuals whose names have been filled in are posted but they do not attain to where they have been assigned to work, that is why there is the challenge of shortage of workforce in primary schools in Taraba state.

Figure 2: Number of Teachers in Primary Schools, 1999-2014

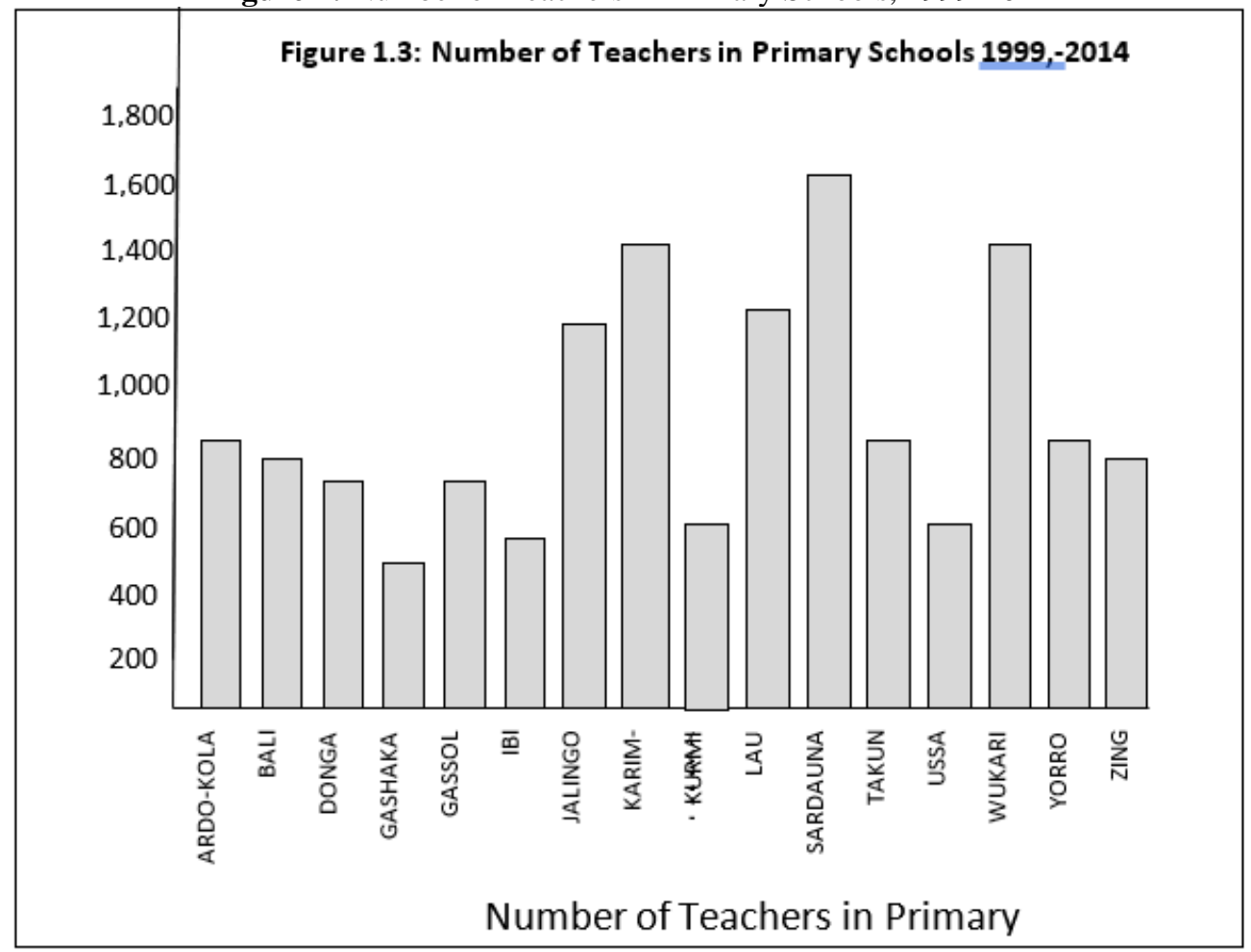

Source: Taraba State Annual Census 2014/2015 Report

From figure 5, the situation of primary education in Taraba state is seemingly pathetic as there are not enough teachers in primary schools to handle foundational education of children seeking to receive a formal education. Evidence abounds that it is only Sardauna Local Government Area that has the highest number of teachers with about 1600 teachers, followed by Karim-Lamido and Wukari which stood at 1400 respectively. Lau and Jalingo have 1200 each, and Ardo-Kola, Donga, Bali, Gassol, Takum, Yoro and Zing Local Government Areas are within the range of 800 and 600 teachers. The 
local governments with fewer numbers of teachers are Gashaka, Kurmi, Ibi and Ussa Local Government Areas which stood at between 400 and 600 teachers respectively.

In these local government areas, teachers are not paid regularly. Incidentally, the Taraba state government is blamed for non-regular payment of primary school teachers because of the lack of local government autonomy from the state. The character of lack of constant and on-time payment of salaries of teachers in public primary schools has remained some of the challenges that bedevil educational development at that level. Teachers in most of these primary schools because of the nonchalant attitude of the government have resorted to other means of survival. In this context, as Akindutire and Ekundayo (2012) posited, the government needs to motivate teachers to encourage new entrants to the profession and retain the old ones on the job. From the foregoing context, Jokthan (2013:184) is not out of place to state that teaching profession though it is undepinned primarily by intrinsic motivation; extrinsic factors also play a major role in retaining them.

Unfortunately, as Akindutire (2001) pointed out, since the 1980s there had been poor funding of the teacher education in Nigeria. The crisis associated with funding teacher education affects the credibility of teachers across the country and the delivery of the education services required of them in the various schools where they are employed. In Taraba state, the case is not any different as teacher training and retraining through the concerted effort of the government to ensure an improved education system at all levels of schools in the state is not given keen interest. Teachers who refuse to take initiative to engage in self-development are allowed to perish. The sad story of most teachers in Taraba state is that after receiving high education and returning on the job, especially at the primary school level, they are not upgraded or promoted as their decision to acquire further education was not approved by the Ministry of Education. Even those who have received approval, who eventually are either upgraded or promoted, often do not have such implemented in their salaries. This situation further erodes the commitment of teachers to teaching as a profession in Taraba state.

Although the challenges of education in Taraba state appear to be mainly associated with primary education, the case in secondary and tertiary education in the state is the same. The secondary schools' teachers do not receive motivation of any kind either for furthering of their education through the in-service scheme or an improved payment and other benefits associated with the social service delivery they offer. These categories of people are treated as the most and highest-paid civil servants in the state, therefore they should not make demands on the state for better or improved working conditions. At the level of the secondary and tertiary education in Taraba state, to borrow from Mmadike (2006) teachers and lecturers have excess workload, 
low morale, inadequate remuneration, unattractive prospects for promotion and inadequate working condition, and are contributing to the nonchalant attitude of teachers and lecturers to their respective job.

Taking the case of pre-primary, primary, junior and senior secondary schools in Taraba state, as presented in table 4 it is deductible that the government of Taraba state within the study period did not effectively deliver the supply-side of democracy through social service provision in the education sector. At the pre-primary and primary schools level, on the average there are a total of 562,986 pupils with only 16,096 teachers. The Junior Secondary Schools have a total of 46,603 students with 1,877 teachers while the Senior Secondary Schools have a total of 14,383 students with only 2,221 teachers of both male and female gender in the Taraba state.

Table 4: Number of Public Schools Enrolment and Teachers, 2014/2015

\begin{tabular}{|l|l|l|l|l|l|l|l|}
\hline & & \multicolumn{2}{|l|}{ Number of Pupils/Students } & \multicolumn{2}{|l|}{ Number of Teachers } \\
\hline Level & $\begin{array}{l}\text { Number of } \\
\text { Schools }\end{array}$ & Male & Female & Total & Male & Female & Total \\
\hline $\begin{array}{l}\text { All Pre-Primary and } \\
\text { primary }\end{array}$ & 1,826 & 308,262 & 254,724 & 562,986 & 10,910 & 5,186 & 16,096 \\
\hline Junior secondary only & 225 & 27,224 & 19,379 & 46,603 & 1,427 & 450 & 1,877 \\
\hline Senior school only & 194 & 19,507 & 14,383 & 33,890 & 1,759 & 462 & 2,221 \\
\hline Total & $\mathbf{2 , 2 4 5}$ & $\mathbf{3 5 4 , 9 9 3}$ & $\mathbf{2 8 8 , 4 8 6}$ & $\mathbf{6 4 3 , 4 7 9}$ & $\mathbf{1 4 , 0 9 6}$ & $\mathbf{6 , 0 9 8}$ & $\mathbf{2 0 , 1 9 4}$ \\
\hline
\end{tabular}

Source: Taraba State Annual School Census, 2014/2015

Translating the data in table 4, with keen interest on the total number of pupils/students and teachers, it shows that the number of the former has been greater than the number of the later. However, the bulk of the population is among the pupils in pre-primary and primary schools while the number of teachers at that level is grossly inadequate. Although similar situation is presented in both Junior and Senior Secondary Schools respectively, the total number of students at the level within the period of investigation appears to be less compared to the number of pupils.

The level of academic performance of students is intrinsically linked to a number of factors, which include both human and material resources. The quality of the teachers in the schools is one of the major factors that determine the level of knowledge transmission. Taraba state is considered to have 51 percent of qualified teachers teaching in primary schools, which means 49 percent of the teachers are unqualified. At the Junior Secondary School level, the state is considered to have 85 percent of qualified teachers with only 15 percent unqualified (Universal Basic Education Commission, 2010). At the Senior Secondary School level, the percentage of qualified teaching staff account for 95 percent with only 5 percent unqualified (Taraba State Universal Basic Education Board, 2010). The education sector in Taraba state presents enormous challenges that undermine the effective delivery of teaching and 
learning on the part of the students. The challenges faced by the education sector in Taraba state relates to the attitude of the government to the sector. Of both Nyame and Suntai administrations, the highest budgetary allocation in the education sector was 15.9 percent in 2009 and the lowest was 4.7 percent in 2002. This situation is not uncommon to Nigeria as a country.

There are implications of inadequate resources/facilities on academic performance on students. The students' performance in the terminal examination has been very poor over the years in the state as shown in table 5. The findings show that the performance of students with credit passes in five subjects including English language and Mathematics which are the basic requirements for transiting to the next level (tertiary institution) has not exceeded 15 percent in the last decade.

Table 5: Students performance in WAEC in Taraba state, 1999-2014

\begin{tabular}{|l|l|l|l|l|}
\hline $\begin{array}{l}\text { S/ } \\
\text { N }\end{array}$ & Year & $\begin{array}{l}\text { Total No. of Registered } \\
\text { Students }\end{array}$ & $\begin{array}{l}\text { No. with 5 Credits and } \\
\text { above }\end{array}$ & Percentage (\%) \\
\hline 1 & 1999 & N/A & N/A & N/A \\
\hline 2 & 2000 & N/A & N/A & N/A \\
\hline 3 & 2001 & N/A & N/A & N/A \\
\hline 4 & 2002 & 9,962 & 1,554 & 15.6 \\
\hline 5 & 2003 & 9,581 & 933 & 10.0 \\
\hline 6 & 2004 & 10,599 & 362 & 3.4 \\
\hline 7 & 2005 & 12,019 & 810 & 6.7 \\
\hline 8 & 2006 & 11,979 & 1,290 & 10.8 \\
\hline 9 & 2007 & 12,198 & 1,353 & 11.1 \\
\hline 10 & 2008 & 16,064 & 1,677 & 10.4 \\
\hline 11 & 2009 & 12,154 & 1,011 & 8.3 \\
\hline 12 & 2010 & 9,665 & 1,087 & 11.2 \\
\hline 13 & 2011 & 13,647 & 2,100 & 15.4 \\
\hline 14 & 2012 & N/A & N/A & N/A \\
\hline & 2013 & N/A & N/A & N/A \\
\hline & 2014 & 24,588 & 3,762 & 15.30 \\
\hline
\end{tabular}

Source: Adopted from Oruonye, 2014. N/A: Not Available.

In terms of academic performance, the Junior Secondary School which is part of the Universal Basic Education (UBE) also has suffered greatly due to the challenges of grossly inadequate staffing in Taraba state. Since the inception of the UBE programme in the state, no teacher has been posted to the Junior Secondary School except the principals (Oruonye and Abbas, 2011). This informs the reason for why most junior secondary schools use borrowed teachers from the primary section and senior secondary schools to teach at the Junior Secondary Schools. Some communities through the Parent Teachers Association (PTA) tax themselves to engage the service of National Youth Service Corps (NYSC) members and part-time teachers in the junior secondary schools. The problem of staffing of the junior secondary schools 
has greatly affected the quality of teaching at this level of education, and by extension the standard of education in the state. This problem is fast undermining the gains achieved from the increase in the number of educational institutions in the state. The quality of the services rendered in the secondary schools is far from satisfactory (Oruonye, 2014), and has implications on the democratic governance in the state because democracy thrives and consolidates in an environment of highly politically conscious and active population.

\section{Conclusion}

The study examined the nexus between democratic governance and social service delivery with specific interest in the education sector in Taraba State between 1999 and 2014. Specifically, we investigated Taraba State governments' social service delivery in the education sector. The study found that the Taraba State government programme in the education sector was abysmal. The challenges of the education sector were predicated on the budgetary allocation to the education sector from 1999 to 2014, which was by every standard grossly inadequate for the functionality of the sector. The effects of such paltry allocation on the sector were enormous, especially in the academic performance of pupils and students, as well as the poor condition of educational facilities during the period of study in the state. Thus, we noted that government policies did not bring about enhanced social service delivery in Taraba State. In the context of this study, the Jolly Nyame (1999-2006) and Danbaba Suntai (2007-2014) administrations, did not contribute to the development of the education sector in a way that it could account for enhanced social service delivery manifested through recruitments, discipline and commitment among teachers that will lead to increase in standard and quality of teaching and learning, reflected in students' performance in the state. The reason for the failure in achieving enhanced social delivery in the education sector is as a result of the government inability to allocate the required funds from the budgetary allocation within the period of study.

Consequently, this paper recommends that the provision of education must be prioritised, as it constitutes a cardinal responsibility of the state to provide for its citizens within the context of social service delivery as one of the yardsticks of measuring the performance of democratic governance. Thus, the state legislature should pass a law that domesticates the UNESCO recommendation.

\section{References:}

1. Adesina, A. E. (2011). Perceived impact of primary education on the attainment of Nigeria vision 20:2020. Proceedings of the 2011 International Conference on Teaching, Learning and Change 
held by the International Association for Teaching and Learning (IATEL). http://www.hrmars.com/admin/pics/117.pdf

2. Ake, C. (1981). A Political Economy of Africa. London: Longman Publisher.

3. Ake, C., (1985). Political economy of Nigeria (ed). London: Longman Publisher.

4. Akindutire, I. O. (2001). Effect of stress on on the teaching performance of secondary school teachers. Retrieved from https://hiwriters.com.ng on July 12, 2020.

5. Akindutire, I. O. \& Ekundayo, H. T. (2012) Teacher education in a democratic Nigeria: challenges and the way forward. Educational research, 3(5). 429-435,

6. Akpeji, C. (2013). Why education is declining in Taraba by researchers. Retrieved from m.guardian. ng/news/why on August 18, 2016.

7. Akujuru, C. A. and Enyioko, N. C. (2015). Democracy and social service delivery in Nigeria: A case study of free medical programme of Rivers State Government (2007-2013) (May 3, 2015). Retrieved from https://ssrn.com/abstract $=2602035$ or http://dx.doi.org/10.2139/ssrn.2602035 on 17 September, 2017.

8. Almond, G. A., Powell, G. B., Strom, K. nd Dalton, R. J. (2007) Comparative politics today: A world view ( ${ }^{\text {th }}$ Edition). India: Dorling Kindersley Pvt. Ltd.

9. Asodike, J. D. \& Ikpitibo, C. L. (2014) Basic issues in primary education delivery in Nigeria. January 8, (1) 150-164.

10. Ayo, B. S. (1988). Social Policy. In V. Ayeni \& S. Kayode (eds), Nigeria's Second Republic: Presidentialism, politics and administration in a Developing State. Lagos: Daily Times Publication.

11. Birch, A. H. (1995). The concepts and theories of modern democracy. London: Routledge

12. Dahl, R. A. (1989). Democracy and its critics. New Haven: Yale University Press.

13. David, S. (2010). The impact of good governance on development and poverty in Africa: Botswana - a relatively successful African initiative. African Journal of Political Science and International Relations 4(7). Retrieved from http://academicjournals.org/ajpsir on 4th June, 2018.

14. Diamond, L., Linz, J. and Lipset, S. M. (1989) (eds.) Democracy in developing countries. Boulder: Tynne Riveriea.

15. Ekpe, E. A. (2011). Globalization of politics and democratic consolidation: A survey and appraisal of Nigeria under the Fourth Republic, 1999 - 2010. In O. A. Bamisaye \& Awofeso (eds), 
Democracy and democratic practice in Nigeria: Issues, challenges and prospects. Lagos: MacGrace Publishers.

16. Federal Republic of Nigeria (2012). National Policy on Education $\left(4^{\text {th }}\right.$ Ed.) Lagos: NERCDC.

17. Ganchok, L. P. (2006). The challenges of leadership in Taraba state 100 days after, what hope for people in the state? Retrieved from http://www.gamji.com/article 6000/NEWS $7434 \mathrm{htm}$ on 30, November 2015.

18. Held, D. (1996) Models of democracy. Cambridge: Polity.

19. Hernandez, C. (2006). Services Sector: It's importance for development and potential impacts of its liberalization. UNDP-Dakar.

20. Hoogwout, M. (2010). English version summary of PhD thesis: The rationality of client-oriented government. De rationalizes, Niuwegein.

21. Jaiyeoba, A. O. (2007). Perceived impact of Universal Basic Education on National development in Nigeria. International Journal of African and African American Studies VI.(1)

22. Johari, (1989). Principles of modern Political Science. New Delhi: Sterling Publications Private Limited

23. Jokthan, Esrom T. (2013) Issues and Challenges in Teacher Recruitment and Retention, JORIND 11(2),. 182-186. December,

24. Kayode, A., Adagba, S. O. and Anyio, S. F. (2013). Corruption and service delivery: The case of Nigeria public service. Wood pecker Journal of Public Administration, 1(1): 001-006.

25. Lysias, D. G. and Fidelis, A. (2014). Democracy and good governance: The missing link in Nigeria. Mediterranean Journal of Social Sciences, 5(16). Retrieved from http://www.mcser.org on $23^{\text {rd }}$ March 2017.

26. Mnadike, A. N. (2006). Teacher education in a democratic NigeriaInternational Research Journals. Retrieved from https://www.interesjournals.org on July 12, 2020

27. Obiweluozor, N. (2015). Early childhood education in Nigeria, Policy implementation: Critique and a way forward. Journal of African Teacher Education, . 4, (1).

28. Olatoun, A. A. (2012) Resource utilization and internal efficiency in Nigerian secondary schools: Implications for socio problems of education. International Journal of Sociology and Anthropology 4(1): 23-30.

29. Olewe, B. N (1995). Development administration. Aba: Grace Ventures.

30. Olewe, B. N and Anga, J. S. (1994). Command administration: The Police perspective. Enugu: New Generation Books. 
31. Quadri, K. (2001). Introduction to primary education studies. Ibadan: Glory Land Publishing Company, Pp. 8-11.

32. Onwe, O. S. and Chibuzor, N. M. (2015). Assessment of National Poverty Reduction Programmes in Nigeria: A study of National Poverty Eradication Programme (NAPEP) in Ebonyi State. International Journal of Humanities and Social Science, 5(2):

33. Oruonye, E. D. (2014). The challenges of quality secondary education in Taraba State. Journal of Education and Social Research 4 (3): 501502.

34. Oruonye, E. D. and Abbas, E. (2011). The geography of Taraba State, Nigeria. Germany: LAP Publishing Company.

35. Taraba State Universal Basic Education Board. (2008). Data on public primary schools teaching \& non teaching staff, Jalingo

36. Ujo, A. A. (2007). Development administration in Nigeria, Kaduna: Joyce Publishers.

37. Umar, H. S. and Tafida, A. D. (2015). Democracy and social welfare services in Nigeria: A perspective of the Fourth Republic. Public Policy and Administrative Research Journal. 5.(2):

38. UNESCO (1998). The State of Education in Nigeria. Lagos, December.

39. UNESCO (2006). World Data on Education - 6th Edition, Nigeria. http://www.ibe.unesco.org/fileadmin/user_upload/archive/Countris/ WDE/2006/SUB-SAHARAN_AFRICA/Nigeria/Nigeria.htm

40. UNICEF (2011). Improving quality and equity in education in Namibia: A trend and gap analysis. Retrieved from https://www.unicef.org/namibia/UNICEF_2011_Ninnes_Trends_and _Gaps_final_combined.pdf on 17 September 2017.

41. UNICEF Report (2014) Nigeria - maternal and child health. https://www.unicef.org/nigeria/children_1926.html on 17 September 2017.

42. Universal Basic Education Commission (2010). 2010 basic education profile: National and regional statistics - Facts and Figures: North East Region. Retrieved from

https://ubeconline.com/Pre/2010\%20Basic\%20Education\%20Profile $\% 20$ Facts $\% 20 \& \% 20$ Figures $\% 20-\% 20$ North\%20East\%20Zone.pdf on 17 August, 2018.

43. Varshney, A. (2000). Why have poor democracies not eliminated poverty? A suggestion. Asian Survey, 40 (5): 718-36.

44. Yusif, M. M. (2008). Education and the war against corruption in Nigeria. Retrieved from mmyusifblogspot.com.ng. on 20 July, 2019. 